\title{
TESTICULAR MORPHOLOGY OF ALBINO RAT; WITHDRAWAL EFFECTS OF CHRONIC ANDROGENIC ANABOLIC STEROID
}

1. Department of Anatomy, UmmulQura University. KSA

2. Department of Anatomy,

Baqai Medical University, Karachi

3. Department of Pharmacology,

Dow University of Health Sciences, Karachi

4. Department of Pharmaceutical Science,

Baqai Medical University, Karachi

5. Department of Pharmaceutical Science,

Baqai Medical University, Karachi

Correspondence Address:

Muhammad MazharHijazi

Department of Anatomy,

UmmulQura University, KSA

drmmazharhijazi@hotmail.com

Article received on:

23/11/2015

Accepted for publication:

13/02/2016

Received after proof reading:

10/03/2016

\section{Dr. Muhammad Mazhar Hijazi', Dr. Muhammad Rashid Ahmed², Dr. Hafiz Syed Imran UI Haq ${ }^{3}$ Syed Naeemul Hassan $\mathrm{Naqvi}^{4}$, Rehana Parveen ${ }^{5}$}

ABSTRACT: Withdrawal effects of chronic androgenic anabolic steroid on hormonal and testicular morphology were studied .Forty five male albino rats were divided into 1) Control 2) Chronic group and 3) Withdrawal group. Testoviron was injected at a dose of 400mg/kg body weight intramuscularly once in two weeks for 14 weeks, and then drug was withdrawan for another 14 weeks. Testes were removed and fixed in $10 \%$ formalin and processed. Following withdrawal of AAS, testicular and relative testicular weight was restored to control. Increased tubular count also returned near to normal while decreased diameter of seminiferous tubules, thickness of germinal epithelium, count and diameter of leydig cells were also restored near to normal in withdrawal group when compared with the chronically treated group. Histological observations also revealed that degenerated spermatogenic cells were returned to their normal appearance and oedematous vacuoles were reduced. Moreover, decreased level of reproductive hormones, i.e. FSH, LH and testosterone also returned to control level in withdrawal group. These results indicated that chronic AAS has substantial harmful effects on hormonal and testicular morphology. However, these adverse effects gradually restored to normal following withdrawal from AAS.

Key words: $\quad$ androgenic anabolic steroids - testis - testicular hormones - rats.

Article Citation: Hijazi MM, Ahmed MR, Imran UI Haq HS, Naqvi SNH, Parveen R. Testicular morphology of albino rat; withdrawal effects of chronic androgenic anabolic steroid. Professional Med J 2016;23(3):343-349. DOI: 10.17957/ TPMJ/16.3188

\section{INTRODUCTION}

Anabolic androgenic steroids (AAS) are the class of steroid hormones that is the synthetic analogue of testosterone. ${ }^{1}$ Their medical usage is restricted and it is only used with caution in male hypogonadism, breast cancer, AIDS, anemia, and bone growth. ${ }^{2-4}$ AAS are commonly abused by body builders and athletes to increase their strength and muscle mass that may persist for months after drug withdrawal. ${ }^{5}$ Long term usage of AAS, cause serious side effects including left ventricular hypertrophy, gynaecomastia, cholestasis, renal failure, elevation of blood pressure, acne, premature baldness, hepatotoxicity and liver cancer. ${ }^{6-11}$

AAS also caused substantial side effects on reproductive systems, both in human and in experimental animals, disturbing the regular endogenous production of testosterone and gonadotrophins.AAS induces hypogonadism that is characterized by reduced testosterone, follicular stimulating hormone (FSH) and leutinizing hormone (LH), altered spermatogenesis and testicular atrophy. ${ }^{12-16}$ Decrease sperm production, altered semen quality and infertility have also been reported. ${ }^{17-19}$ These effects are due to the inhibitory feedback of AAS on hypothalamuspituitary-testicular axis and local suppression of excess steroids on testis. ${ }^{20,21}$ In a recent study, AAS not only decreased the absolute testicular weight and also altered the architecture of seminiferous tubules of Sprague-Dewley rats. ${ }^{22}$ Other studies also confirmed that high dose of AAS also depleted the germ and leydig cell population in testes of rats. ${ }^{17,23-25}$

This study was therefore designed to observe the withdrawal effects of AAS on body weight, testicular and relative testicular weights, hormonal levels and morphology of testes of albino rats with the help of light microscope. 


\section{MATERIALS AND METHODS}

Forty five male albino rats of wistar strain weighing 180-250 were selected in random manner for this study. All animals were kept in experimental room of animal house of Baqai Medical University, under standard animal house condition of $12 \mathrm{hr}$ dark and $12 \mathrm{hr}$ light cycle and temperature of $30 \square \mathrm{C}$. They were fed with standard laboratory diet and water ad libitum. One week prior to start of experiment, they were held in experimental room in close observations to acclimate them with experimental room. After one week of acclimatization to the laboratory environment, the animals were divided into following groups:

Group 1: These animals were given normal saline and served as controls

Group 2: Chronic group, received inj. testoviron, (i.m) for 14 weeks.

Group3: Withdrawal group, discontinuation after 14 weeks of testoviron injection for another 14 weeks.

Testoviron injection was purchased from Schering AG, Germany. Each $\mathrm{ml}$ of testoviron depot is a blend of $110 \mathrm{mg}$ testosterone enanthate and $25 \mathrm{mg}$ testosterone propionate. The drug was introduced intramuscularly at a dose of $400 \mathrm{mg} /$ $\mathrm{kg}$ body weight once in two weeks.

At the end of experiment, animals were sacrificed by decapitation and blood samples were obtained by intracardiac puncture. Testosterone, FSH and LH was determined by using ELISA method.

The testes were removed and fixed in Bouin's fluid. They were subsequently embedded in paraffin wax, sectioned at $3 \mu \mathrm{m}$ and stained with haematoxylin and eosin. The stained slides were then studied under light microscope for tubular count and diameter, thickness of germinal epithelium, nuclear count and diameter of leydig cells.

Data were expressed as mean \pm SEM and statistical analysis was performed by ANOVA followed by Post hoc Tukey test by using SPSS (19). P value less than 0.05 was considered as significant.

\section{RESULTS}

\section{Changes in Body Weight}

Final mean body weight of all three groups had highly significantly increased $(P<0.001)$ when compared with initial mean body weight. While, the weight gain in withdrawal was significantly higher $(P<0.001)$ than to control but significantly less $(P<0.05)$ when compared to chronic group (Table-I).

\begin{tabular}{|c|c|c|c|}
\hline $\begin{array}{c}\text { PARA- } \\
\text { METER }\end{array}$ & CONTROL & CHRONIC & WITHDRAWAL \\
\hline $\begin{array}{c}\text { Initial } \\
\text { body } \\
\text { weight }\end{array}$ & $204.33 \pm 3.96$ & $200.80 \pm 2.50$ & $201.86 \pm 4.26$ \\
\hline $\begin{array}{c}\text { Final body } \\
\text { weight }\end{array}$ & $233.26 \pm 4.50$ & $244.93 \pm 2.63$ & $242.27 \pm 2.97$ \\
\hline $\begin{array}{c}\text { Weight } \\
\text { gain }\end{array}$ & 28.93 & 44.13 & 40.4 \\
\hline $\begin{array}{c}\text { Testicular } \\
\text { weight }\end{array}$ & $12.03 \pm 0.33$ & $9.08 \pm 0.09$ & $11.50 \pm 0.31$ \\
\hline $\begin{array}{c}\text { Relative } \\
\text { testicular } \\
\text { weight }\end{array}$ & $5.13 \pm 0.15$ & $3.71 \pm 0.06$ & $4.82 \pm 0.14$ \\
\hline $\begin{array}{c}\text { Table-I. Body weight, testicular and relative testicular weight } \\
\text { of control and treated animals }\end{array}$ \\
\hline
\end{tabular}

\section{Testicular and relative testicular weight}

The mean testis and relative testis weight of withdrawal group were highly significantly increased $(P<0.001)$ when compared with that of chronically treated rats but it was not significant $(P>0.05)$ when compared with control (Table-I).

\section{Hormonal Results}

The mean serum concentration of testosterone, $\mathrm{FSH}$ and $\mathrm{LH}$ of withdrawal group were significantly higher $(P<0.001)$ than that of chronic group but they were non-significant $(P<0.05)$ when compared with that of control group (Table-II).

\section{Histological Results}

The mean count of seminiferous tubules of withdrawal group was significantly lower $(P>0.001)$ when compared with that of chronically treated group but not significant $(P<0.05)$ when compared with that of control (Table-II, Figure-1). 


\begin{tabular}{|c|c|c|c|}
\hline HORMONAL & CONTROL & CHRONIC & WITHDRWAL \\
\hline TESTSTERONE & $0.82 \pm 0.01$ & $0.25 \pm 0.01$ & $0.74 \pm 0.01$ \\
\hline FSH & $10.82 \pm 0.09$ & $2.66 \pm 0.06$ & $8.25 \pm 0.17$ \\
\hline $\begin{array}{c}\text { LH } \\
\text { SEMINIFEROUS } \\
\text { TUBULES }\end{array}$ & $5.52 \pm 0.10$ & $3.73 \pm 0.06$ & $5.20 \pm 0.09$ \\
\hline $\begin{array}{c}\text { Count } \\
\text { Diameter }\end{array}$ & $16.29 \pm 0.38$ & $24.42 \pm 0.35$ & $16.63 \pm 0.35$ \\
\hline $\begin{array}{c}\text { Thickness } \\
\text { INTERSTITIAL } \\
\text { CELLS }\end{array}$ & $93.83 \pm 1.76$ & $66.56 \pm 1.67$ & $90.19 \pm 1.99$ \\
\hline Count & $13.73 \pm 0.56$ & $6.73 \pm 0.47$ & $12.13 \pm 0.49$ \\
\hline Nuclei & $4.07 \pm 0.05$ & $3.02 \pm 0.06$ & $3.94 \pm 0.09$ \\
\hline & \multicolumn{2}{|c|}{ Table-II. Hormonal Assays } \\
\hline
\end{tabular}
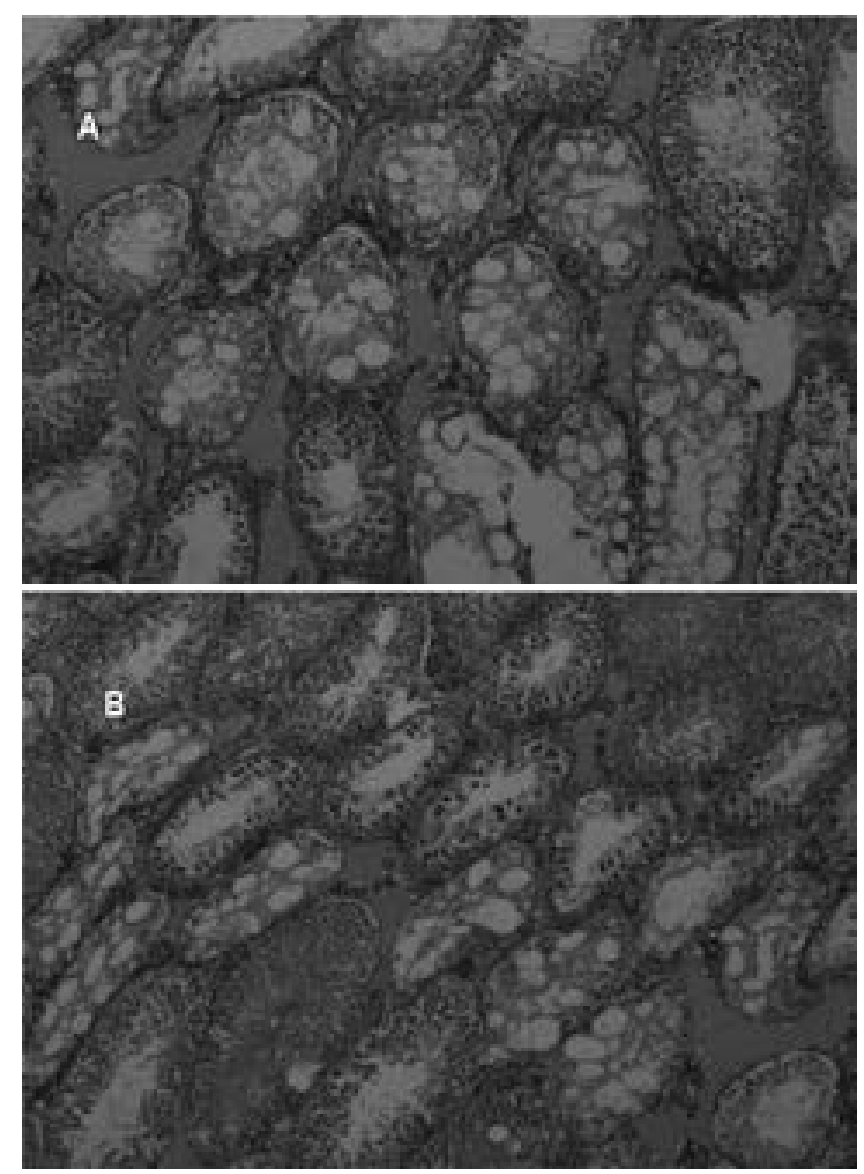

Figure-1: $\mathrm{H} \& \mathrm{E}$ stained $3 \mu \mathrm{m}$ sections of testis of chronic (A) and withdrawal (B) groups. Figure $A$ shows reduced number of seminiferous tubules, reduced thickening of germinal epithelium and degenerative changes. Figure $B$ shows the partial recovery and increase number of tubules, less degenerative changes and normal thickening of germinal epithelium in most of the tubules (220 X).
The mean diameter of seminiferous tubules of withdrawal group was significantly higher $(P>0.001)$ when compared with that of chronically treated group but not significant $(P<0.05)$ when compared with that of control. Also the mean thickness of germinal epithelium of withdrawal group was significantly higher $(P>0.001)$ when compared with the mean thickness of chronically treated group but not significant $(\mathrm{P}<0.05)$ when compared with that of control. (Table-II, Figure1).

The mean count of interstitial cell nuclei of withdrawal group was significantly higher $(P>0.001)$ when compared with the mean count of chronically treated group but not significant $(P<0.05)$ when compared with the mean count of control. Also the mean diameter of interstitial cell nuclei of withdrawal group was significantly higher $(P>0.001)$ when compared with the mean diameter of chronically treated group but not significant $(P<0.05)$ when compared with that of control(Table-II, Figure-2).
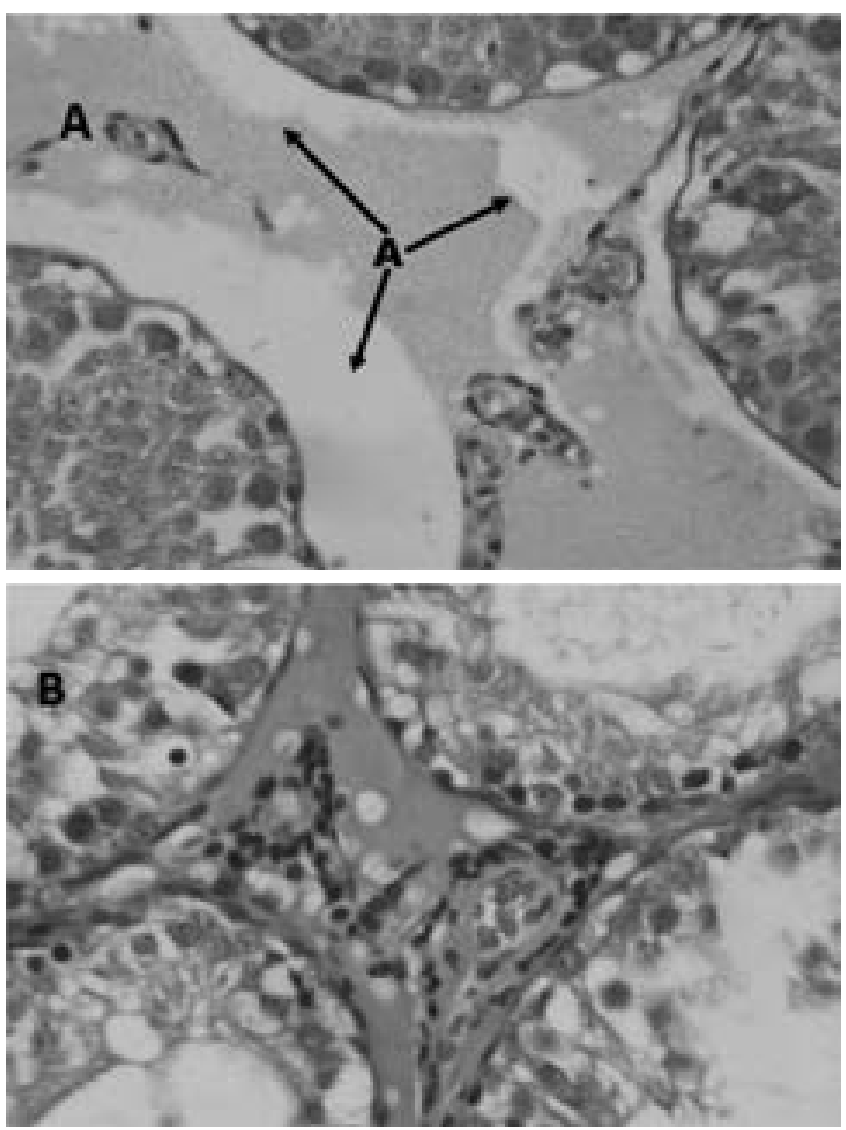
Figure-2: $\mathrm{H} \& \mathrm{E}$ stained $3 \mu \mathrm{m}$ sections of testis of chronic (A) and withdrawal (B) groups. Figure A shows reduced number and diameter of leydig cells and nuclei. Arrow is indicating the wide space between the tubules. Figure B shows the partial recovery and increase number and diameter of leydig cells and nuclei. Narrowing of the interstitial space between the tubules is also seen $(400 \mathrm{X})$.

A clear reduction of spermatogenic cells with degenerated spermatogonia and spermatocytes which were observed in tubules of chronically treated animal were returned back to the normal in withdrawal group. The tubular lumen was still enlarged but majority of them were found to contain morespermatogonia, spermatocytes and spermatozoa than chronically treated animals (Figure-3). Oedamatous vacuoles which were formed and concentrated mainly opposite to the boundary of the tubules were reduced in numbers in most of the tubules of withdrawal group (Figure-3).
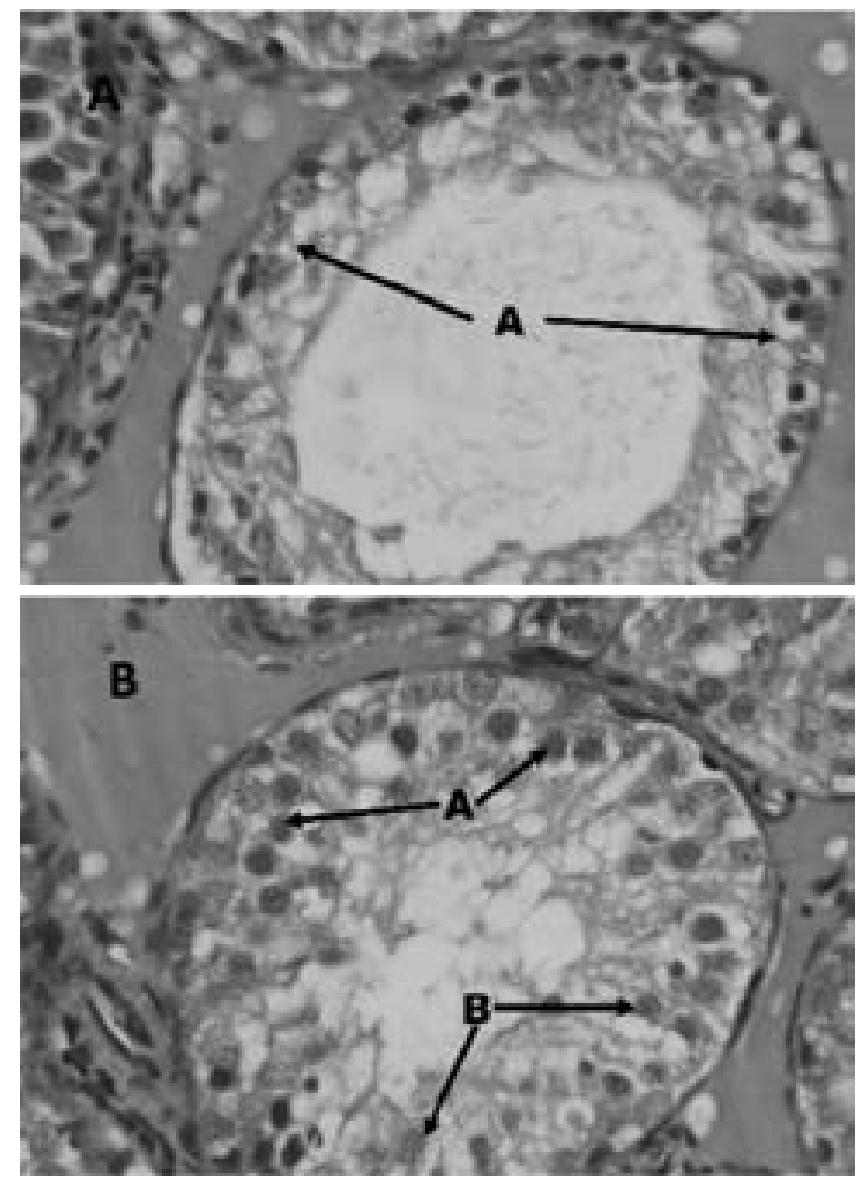

Figure-3: $\mathrm{H} \& \mathrm{E}$ stained $3 \mu \mathrm{m}$ sections of testis of chronic (A) and withdrawal (B) groups. Figure A shows reduced number of spermatogonia(arrow), primary and secondary spermatocytes and absenceofspermatozoa. FigureBshowsthepartial recovery and increase number of spermatogonia, primary and secondary spermatocytes (arrow A \& B) and few spermatozoa (400 X).

\section{DISCUSSION}

AAS usage in athletes and in body builders to increase their muscle mass, physical strength and performance is a common practice. Large identifiable studies have shown the potential toxic effects of AAS on male reproductive systems both in experimental animals and human. ${ }^{13,26}$

This study was performed to observe and record the withdrawal effects of AAS on morphology of testes with the help of light microscope.

In the present study, the weight gain in withdrawal group was significantly more than to control but it was significantly lower than to chronic group. This result are in line that following discontinuation of AAS, increase muscle mass and weight gain fade slowly and it may persist up to several weeks and recover partially. ${ }^{27,28}$ Similarly, significant recovery in the testicular and relative testicular weight was also noted near to control animals following withdrawal from AAS. ${ }^{29}$

Our result showed the reversibility of $\mathrm{FSH}, \mathrm{LH}$ and testosterone level near to control following withdrawal of AAS that is contrast to other findings that $\mathrm{FSH}$ and $\mathrm{LH}$ sustained suppression for a period of one year after withdrawal from AAS. ${ }^{30}$ Kanayama et al (2015) also found that after 326 month from discontinuation of AAS, serum testosterone level retained to lower levels in AAS using weight lifters as compare to non-AAS using weightlifters. ${ }^{13}$

AAS exerts a negative feedback to hypothalamustesticular axis that results into suppression of testicular function that is characterized by decreased production of testosterone, suppression of spermatogenesis and atrophy of testis. ${ }^{21,23}$ In the present study, chronic treatment 
of AAS halted the process spermatogenesis as indicated by the decrease number of primary and secondary spematocytes, spermatids and spermatozoa. ${ }^{25}$ These changes could be due to reduction of size and shape of seminiferous tubules which halted the smoothness of spermatogenesis. $^{22}$ When animals were left untreated for fourteen weeks, decrease number of primary and secondary spematocytes, spermatids and spermatozoa improved to control level. This recovery could be due to recovery of the process after some weeks following discontinuation of AAS. $^{2}$

Our study showed the remarkable reduction of number and size of leydig cells, widening of interstitial space and appearing of fibroblast cells in chronically treated rats..$^{16,20,31}$ Moreover, our study showed that number and size of leydig cells was restored near to normal in withdrawal group. Our study is in line with the results of some researchers ${ }^{32}$ but contrast with the finding of others that depletion of leydig cells was not reversible after withdrawal of AAS. ${ }^{17}$

AAS had a negative impact on germ cell that resulted into more number of tubules per field. ${ }^{25}$ In our study, tubular count of withdrawal group restored to control level. This recovery could be due to the reversal of testosterone to control level because optimal level of testosterone maintains the normal architecture of seminiferous tubules. ${ }^{32}$

The tubular diameter and germinal epithelium thickness were also highly significantly decreased in chronic treated group. The germinal epithelium was disrupted, copious vacuoles were seen and broad spaces appeared between the cellular components. Two layer spermatocytes layer decreased into one layer and four to five layer thick zones of spermatids were decreased into two to three layers thick. These findings are in consistent with the previous reports that chronic AAS alter the testicular function and ceased the maturation of germ cell population with reduction in germ layer thickness. Moreover, disruption of cellular components of germinal epithelium led into decrease diameter and disorganization of seminiferous tubules hence wide spaces appear between tubules. ${ }^{16,25}$ However, reversibility of tubular diameter and germinal epithelium thickness to control after withdrawal from AAS were observed. These effects may be due to the restoration of testosterone and $\mathrm{LH}$ after withdrawal that helps to mature the germ cells and precede normal spermatogenesis that maintains the tubular diameter. ${ }^{33,34}$

It is concluded that chronic AAS has substantial harmful effects on hormonal and testicular morphology. However, these adverse effects gradually restored to normal following withdrawal from AAS. Further studies are warranted to evaluate the exact mechanism of toxicity and recovery.

Copyright (C) 13 Feb, 2016.

\section{REFERENCES}

1. Dotson JL, Brown RT. The history of the development of anabolic-androgenic steroids. Pediatric clinics of North America. 2007;54(4):761-9, xi.

2. Samplaski MK, Loai Y, Wong K, Lo KC, Grober ED, Jarvi KA. Testosterone use in the male infertility population: prescribing patterns and effects on semen and hormonal parameters. Fertility and sterility. 2014;101(1):64-9.

3. Robles-Diaz M, Gonzalez-Jimenez A, Medina-Caliz I, Stephens C, Garcia-Cortes M, Garcia-Munoz B, et al. Distinct phenotype of hepatotoxicity associated with illicit use of anabolic androgenic steroids. Alimentary pharmacology \& therapeutics. 2015;41(1):116-25.

4. Watson S, Fuqua JS, Lee PA. Treatment of hypogonadism in males. Pediatric endocrinology reviews : PER. 2014;11 Suppl 2:230-9.

5. Momaya A, Fawal M, Estes R. Performance-enhancing substances in sports: a review of the literature. Sports medicine (Auckland, NZ). 2015;45(4):517-31.

6. Sondergaard EB, Thune JJ, Gustafsson F. Characteristics and outcome of patients with heart failure due to anabolic-androgenic steroids. Scandinavian cardiovascular journal : SCJ. 2014;48(6):339-42.

7. Rahnema CD, Crosnoe LE, Kim ED. Designer steroids - over-the-counter supplements and their androgenic component: review of an increasing problem. Andrology. 2015;3(2):150-5. 
8. Bayerl C. Body-Builder Acne. Pathogenesis and Treatment of Acne and Rosacea: Springer; 2014. p. 259-63.

9. Shamloul RM, Aborayah AF, Hashad A, Abd-Allah F. Anabolic steroids abuse-induced cardiomyopathy and ischaemic stroke in a young male patient. BMJ case reports. 2014;2014.

10. Hardt A, Stippel D, Odenthal M, Holscher AH, Dienes HP, Drebber U. Development of hepatocellular carcinoma associated with anabolic androgenic steroid abuse in a young bodybuilder: a case report. Case reports in pathology. 2012;2012:195607.

11. Awai HI, Yu EL, Ellis LS, Schwimmer JB. Liver toxicity of anabolic androgenic steroid use in an adolescent with nonalcoholic fatty liver disease. Journal of pediatric gastroenterology and nutrition. 2014;59(3):e32-3.

12. Noorafshan A, Karbalay-Doust S, Ardekani FM. High doses of nandrolone decanoate reduce volume of testis and length of seminiferous tubules in rats. APMIS : acta pathologica, microbiologica, et immunologica Scandinavica. 2005;113(2):122-5.

13. Kanayama G, Hudson JI, DeLuca J, Isaacs S, Baggish $\mathrm{A}$, Weiner $\mathrm{R}$, et al. Prolonged hypogonadism in males following withdrawal from anabolic-androgenic steroids: an under-recognized problem. Addiction (Abingdon, England). 2015;110(5):823-31.

14. Coward RM, Rajanahally S, Kovac JR, Smith RP, Pastuszak AW, Lipshultz LI. Anabolic steroid induced hypogonadism in young men. The Journal of urology. 2013;190(6):2200-5.

15. Woodhill I, Cooper C, Zacharin M, Cukier K, Vuillermin P. Low testosterone in a male adolescent bodybuilder: Which diagnosis holds more weight? Journal of paediatrics and child health. 2014;50(9):739-41.

16. Mesbah SF, Shokri S, Karbalay-Doust S, Mirkhani H. The effect of nandrolone decanoate on the body, testis and epididymis weight and semen parameters in adult male rats. Iranian Journal of Medical Sciences. 2015;32(2):93-9.

17. Feinberg MJ, Lumia AR, McGinnis MY. The effect of anabolic-androgenic steroids on sexual behavior and reproductive tissues in male rats. Physiology \& behavior. 1997;62(1):23-30.

18. Karbalay-Doust $\mathrm{S}$, Noorafshan A, Ardekani FM, Mirkhani $\mathrm{H}$. The reversibility of sperm quality after discontinuing nandrolone decanoate in adult male rats. Asian journal of andrology. 2007;9(2):235-9.

19. Torres-Calleja J, Gonzalez-Unzaga M, DeCelis-Carrillo
R, Calzada-Sanchez L, Pedron N. Effect of androgenic anabolic steroids on sperm quality and serum hormone levels in adult male bodybuilders. Life sciences. 2001;68(15):1769-74.

20. Janjic MM, Stojkov NJ, Andric SA, Kostic TS. Anabolicandrogenic steroids induce apoptosis and NOS2 (nitric-oxide synthase 2) in adult rat Leydig cells following in vivo exposure. Reproductive toxicology (Elmsford, NY). 2012;34(4):686-93.

21. Dohle GR, Smit M, Weber RF. Androgens and male fertility. World journal of urology. 2003;21(5):341-5.

22. Mohd Mutalip SS, Surindar Singh GK, Mohd Shah A, Mohamad M, Mani V, Hussin SN. Histological changes in testes of rats treated with testosterone, nandrolone, and stanozolol. Iranian journal of reproductive medicine. 2013;11(8):653-8.

23. Stojkov NJ, Janjic MM, Bjelic MM, Mihajlovic Al, Kostic TS, Andric SA. Repeated immobilization stress disturbed steroidogenic machinery and stimulated the expression of cAMP signaling elements and adrenergic receptors in Leydig cells. American journal of physiology Endocrinology and metabolism. 2012;302(10):E1239-51.

24. Shokri S, Aitken RJ, Abdolvahhabi M, Abolhasani F, Ghasemi FM, Kashani I, et al. Exercise and supraphysiological dose of nandrolone decanoate increase apoptosis in spermatogenic cells. Basic \& clinical pharmacology \& toxicology. 2010;106(4):32430.

25. Hijazi MM, Azmi MA, Hussain A, Naqvi S, Perveen R, Hijazi S. Androgenic Anabolic Steroidal-Based Effects on the Morphology of Testicular Structures of Albino Rats. Pakistan journal of zoology. 2012;44(6):1529-37.

26. Garevik N, Rane A, Bjorkhem-Bergman L, Ekstrom L. Effects of different doses of testosterone on gonadotropins, 25-hydroxyvitamin D3, and blood lipids in healthy men. Substance abuse and rehabilitation. 2014;5:121-7.

27. Hartgens F, Kuipers H. Effects of androgenic-anabolic steroids in athletes. Sports medicine (Auckland, NZ). 2004;34(8):513-54.

28. van Amsterdam J, Hartgens F. Acute and chronic adverse reaction of anabolic-androgenic steroids. Adverse Drug Reaction Bulletin. 2014;288(1):1111-4.

29. McGinnis MY, Lumia AR, Possidente BP. Effects of withdrawal from anabolic androgenic steroids on aggression in adult male rats. Physiology \& behavior. 2002;75(4):541-9. 
30. Garevik N, Strahm E, Garle M, Lundmark J, Stahle L, Ekstrom $L$, et al. Long term perturbation of endocrine parameters and cholesterol metabolism after discontinued abuse of anabolic androgenic steroids. The Journal of steroid biochemistry and molecular biology. 2011;127(3-5):295-300.

31. Grokett BH, Ahmad N, Warren DW. The effects of an anabolic steroid (oxandrolone) on reproductive development in the male rat. Acta endocrinologica. 1992;126(2):173-8.

32. Nagata S, Kurosawa M, Mima K, Nambo Y, Fujii
Y, Watanabe G, et al. Effects of anabolic steroid (19-nortestosterone) on the secretion of testicular hormones in the stallion. Journal of reproduction and fertility. 1999;115(2):373-9.

33. Schlatt S, Ehmcke J. Regulation of spermatogenesis: an evolutionary biologist's perspective. Seminars in cell \& developmental biology. 2014;29:2-16.

34. Khaneshi F, Nasrolahi O, Azizi S, Nejati V. Sesame effects on testicular damage in streptozotocin-induced diabetes rats. Avicenna journal of phytomedicine. 2013;3(4):347-55.

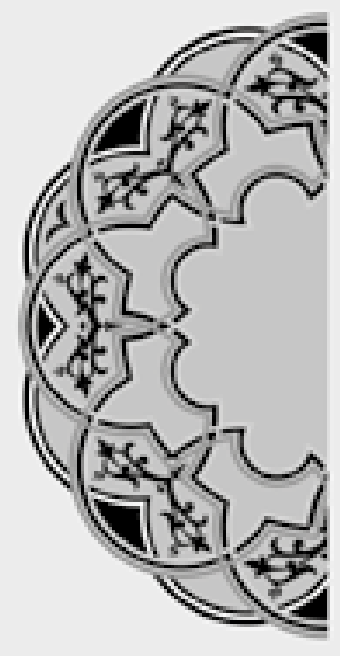

\section{"Even the nicest people have their limits."}

Unknown

AUTHORSHIP AND CONTRIBUTION DECLARATION

\begin{tabular}{|c|c|c|c|}
\hline Sr. \# & Author-s Full Name & Contribution to the paper & Author $=$ s Signature \\
\hline 1 & Dr. M. Mazhar Hijazi & $\begin{array}{l}\text { Conception, Planning \& } \\
\text { Interpretation }\end{array}$ & \\
\hline 2 & Dr. M. Rashid Ahmed & Dissection of Rats & \\
\hline 3 & Dr. Hafiz Syed Imran UI Haq & Data collection \& Analysis & \\
\hline 4 & Syed Naeemul Hassan Naqvi & Critical Review & \\
\hline 5 & Rehana Parveen & Revision & RE \\
\hline
\end{tabular}

